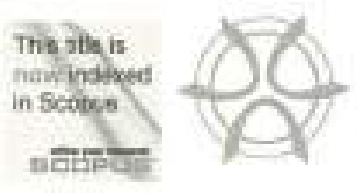

\section{IMPACTS OF URBAN LAND USE ON CRIME PATTERNS THROUGH GIS APPLICATION}

\author{
Ahmad Nazri Muhamad Ludin', Norsiah Abd. Aziz ${ }^{2}$, \\ Nooraini Hj Yusoff ${ }^{3} \&$ Wan Juliyana Wan Abd Razak ${ }^{4}$ \\ ${ }^{1,2.34}$ Centre for Innovative Planning and Development (CiPD) \\ Facuity of Built Environment \\ UNIVERSITI TEKNOLOGI MALAYSIA
}

Abstract

Land use planning plays a crucial role in creating a balance between the needs of society, physical development and the ecosystem. However, most often poor planning and displacement of land uses particularly in urban areas contribute to social ills such as drug abuse and criminal activities. This research explains the spatial relationship of drug abuse and other criminal activities on urban land use planning and their implications on the society at large. Spatial statistics was used to show patterns, trends and spatial relationships of crimes and land use planning. Data on crime incidents were obtained from the Royal Malaysia Police Department whilst cases of drug abuse were collected from the National AntiDrug Agency (AADK) . Analysis of the datn together with digital land use maps produced by Ampang Jaya Municipal Council, showed the distribution of crime incidents and drug abuse in the area. Findings of the study also indicated that, there was a strong relationship between petty crimes, drug abuse and land use patterns. These criminal activities tend to concentrate in residential and commercial areas of the study area.

Keywords: Drug abuse, land use planning, GIS/spatial statistics, criminal activities

\footnotetext{
'Profeseor at Depariment of Dhan and Regional Hanning, Faculty of Buila Envirownent, Lniversiti Toknalogi Malaysia.. Email: b-uasaigutmany (Coeresponding Authar)
} 


\section{INTRODUCTION}

Fear of crime and insecurity are realities of urban life. Criminal activities and drug abuse in particular, continue to raise concerns in most developing countries. Between 1980 and 2004, the total erime index in Malaysia increase by $90 \%$ and most of which are related to properties (Sidhu 2006). Malaysia is ranked 50 out of 60 countries in terms of total crime per capita with an average of 6.97 per 1,000 people (Nations Master 2010). Vasudevan (2004) ranked the top 6 issues in Malaysia to be crime and public safety (46\%), followed by social and moral problems $(12 \%)$, economy $(9 \%)$, domestic policies $(7 \%)$, unemployment $(4 \%)$ and education $(4 \%)$.

Cities as socioeconomic hubs attract people of diverse interests and backgrounds including those susceptible to perpetrate eriminal activities. Criminal activities are complex phenomenat, and researchers agreed that there is a link between criminal activities with physical and social space. Opportunity theory implies that crime density and population density are conceptually related, in that the probabilities of predatory interactions between individuals and their property increase as a function of persons per unit arca (Harries 2006). Crime opportunity takes place when the offender finds a target in suitable situntion without a capable guardian in the urban physical environment (Tabagin et al. 2008; Chainey and Rateliffe 2005; Klinkenber 2008). Criminal pattem theory reveals that offenders tend to concentrate in areas fumiliar to them and through their day-to-day activities watch for an easy target and an open space for a quick and easy escape route before committing a crime. Population density and total area are expected to influence the influx of crime incidence in housing scheme. This fact is supported by Gymfi (2002) through a crime pattern study in Ghana where crime is highest in developed and densely populated regions. Hence, there is a relationship between crime, the offender and the environment,

Generally, it is a criminal activity to use, own, preduce or distribute drugs classified as having the potential to be abused. Drug abuse is closely related to crime due to its consumption without legal prescription. It affects individual behaviour and/or habit, and is potential for violence and petty crimes such as snatch theft. Drug abuse and unemployment are among the driving factors for the increase of snatch theft crime (Allen 2005). In fact, $50 \%$ of snatch thefts that occurred in Kuala Lumpur in 2009 are believed to be committed by drug addicts (Utusan Online 2009).

Due to the increasing rate of crime each year, the Malaysian government in January 2012 has introduced and launched Govemment Transformation Programme (GTP). This programme is designed to provide all Malaysians the 
access to improved public services irrespective of race, religion and region. GTP is created based on public concems about some major issues that affected the nation. The focus of attention under GTP is the implementation of the National Key Result Area or NKRA. NKRA involves 7 key areas and the performance of each area is evaluated through specific Key Performance Index (KPI). In order to measure and improve the efficiency and quality of government services, one of the NKRA initiatives is on reduction of crime.

Following the NKRA initiatives, the Federal Town and Country Planning Department introduced a Safe City Programme and embrace Crime Prevention through Environmental Design (CPTED) concept with the objectives to reduce crime incidence and improve the quality of life (JPBD 2010). Under this programme, the safe city is defined as a city that is free of any threats physically, socially and mentally, and is a protected environment. While, CPTED basically emphasises on the idea that proper design and effective use of the built environment can lead to a reduction of crime incidence (Schneider \& Kitchen 2013).

Hence, this research attempts to evaluate the relationship and influence of land use planning on the distribution patterns of drug abuse and criminal activities. Spatial statistics techniques are used to generate spatial analysis mode] and hotspot areas. Ampang Jaya Municipal Council (AJMC) is selected as the study area because it has one of the highest population densities in Selangor. This study focuses on theft and snatch theft with the assumption that these crimes are often drug related erimes.

\section{THE RELATIONSHIP BETWEEN CRIMINAL ACTIVITIES, DRUG ABUSE AND LAND USE}

Suryavanshi (2001) contends that there is a relationship between land use, urban form, routine activities and crime. Figure 1 shows the relationship between land use and opportunities for crime through two other important factors namely routine activities and urban form. 


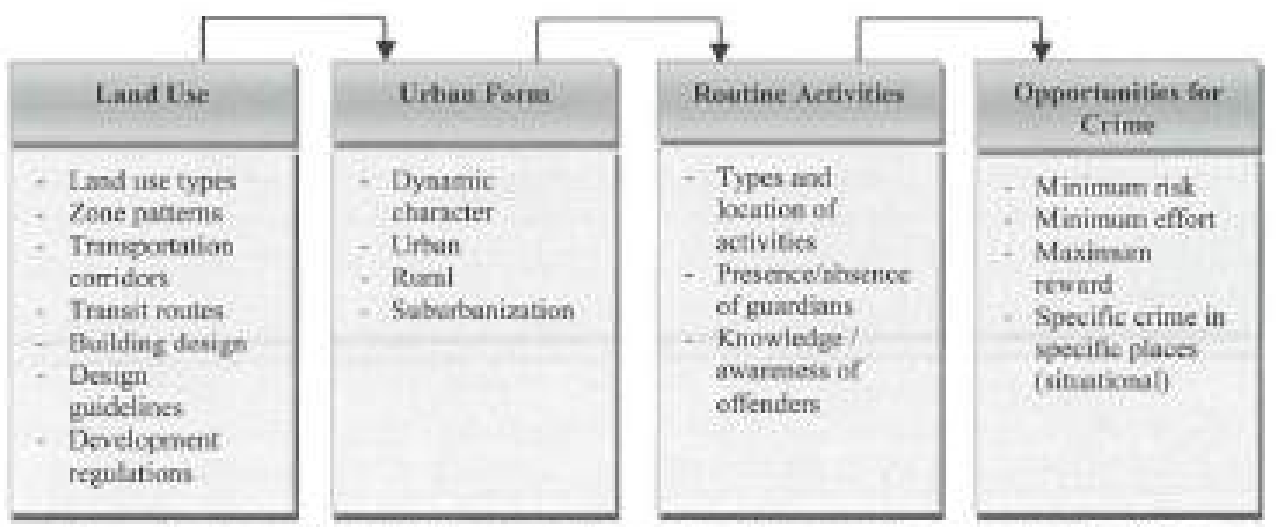

Figure I: Theoretical Relationship between Land Use and Opportunities for Crime

\section{Drug Abuse and Criminal Activities}

Brochu (1995) and Fisher et al. (1999) observed that individuals whom have developed an extreme dependency on drug tend to be involved in criminal activities such as prostitution, theft of property and fraud, Karofi (2005) argued that drug abuse and criminal behaviours are closely related to subeulture, socioeconomic factors and rural-urban migration. He further explained that subculture is a situation where an individual lives among drug addict friends that later ends up in drug trafficking and consumption. Thus, for a continuous supply of drugs, criminal acts are committed as an easy eaming, In addition, socio-ceonomic factors such as poverty, broken homes, environment and urbanization, and ruralurban migration atso contribute to criminal acts. The pressure of life coupled with the increasing standurd of living in urban areas has resulted in these individuals to choose the easy way out in fulfilling their needs regardless of the impact and consequences of their actions on the community.

\section{Criminal Activities and Land Use}

As land use change with new development and redevelopment, the structure of urban form will change as well (Brantinghams 1981; Felson 1987), Urban forms are dynamies; any change in land use may bring about other changes to nearby areas. For instance, the development of a new community facility may change the routine activities of the community involved. According to Felson (1987) routine activities would create crime opportunities for the offender. Property crimes are higher at places where there are dispersed shopping and strip commercial developments. Commercial areas in cities have been found to be prone to burglaries and thefts while residential areas are conducive to crimes such as 
sexual offence and murders. Studies have also indicated that child-sex offences and juvenile crimes are much higher near areas where high schools are located (Suryavanshi 2005).

\section{GIS Application in Crime Pattern Analysis}

Crime patterns can be analysed and explained using GIS because it offers a medium to analyse criminal activities data for a better understanding of the factors that infiuence crime offenders. It could also be used to generate a model that would predict potential crime spots. GIS could be applied for the analysis and the mapping of crime data for both academic research and practical law enforcement (Murray et. al. 2001). This is more so because it offers tools for the modelling of statistical surfaces that facilitate approximate visualisations of point densities (Harries 2006). The level of analysis achieved using GIS could determine even the density of crime within every spatial scale. Spatinl statistics function can be utilized to help authorities such as the police department to map crime scene. This would further assist the authority to understand crime behaviours and find the best action to prevent crime. The methodology employed could assist authorities to better understand the pattern of crime spatially and predict potential crime. Thus, preventive measures can be taken through proper physical planning for new development areas while 'target hardening' measures can be taken for existing developed areas. GIS provide an altemative tool that can aid policy makers, decision makers and the security operatives in particular discharge their core responsibility of ensuring peace and security in the society. The integration of spatial statistics technique and GIS can assist local authorities and police departments to identify hotspots for crime ineidence.

\section{CASE STUDY: MAJLIS PERBANDARAN AMPANG JAYA}

The study area, Majlis Perbandaran Ampang Jaya (MPAJ) or Ampang Jaya Municipal Council covers Mukim Ampang, Mukim Hulu Kelang and part of Mukim Setapak, and is approximately 14,350 bectares. The adjoining councils include Dewan Bandaraya Kuala Lumpur. Majlis Perhandaran Selayang and Majlis Perbandaran Kajang. The map showing MPAJ and its neighbouring municipalities is shown in Figure 2. The population of MPAJ is estimated at 600,000 people in 2007 (Department of Statistics, Malaysia) or $12.7 \%$ of the total population of Selangor. The distriet consists of four planning blocks as shown in Table 1. MPAJ together with Kuala Lumpur has one of the highest population densities in Malaysia due to concentration of economic and institutional activities. 


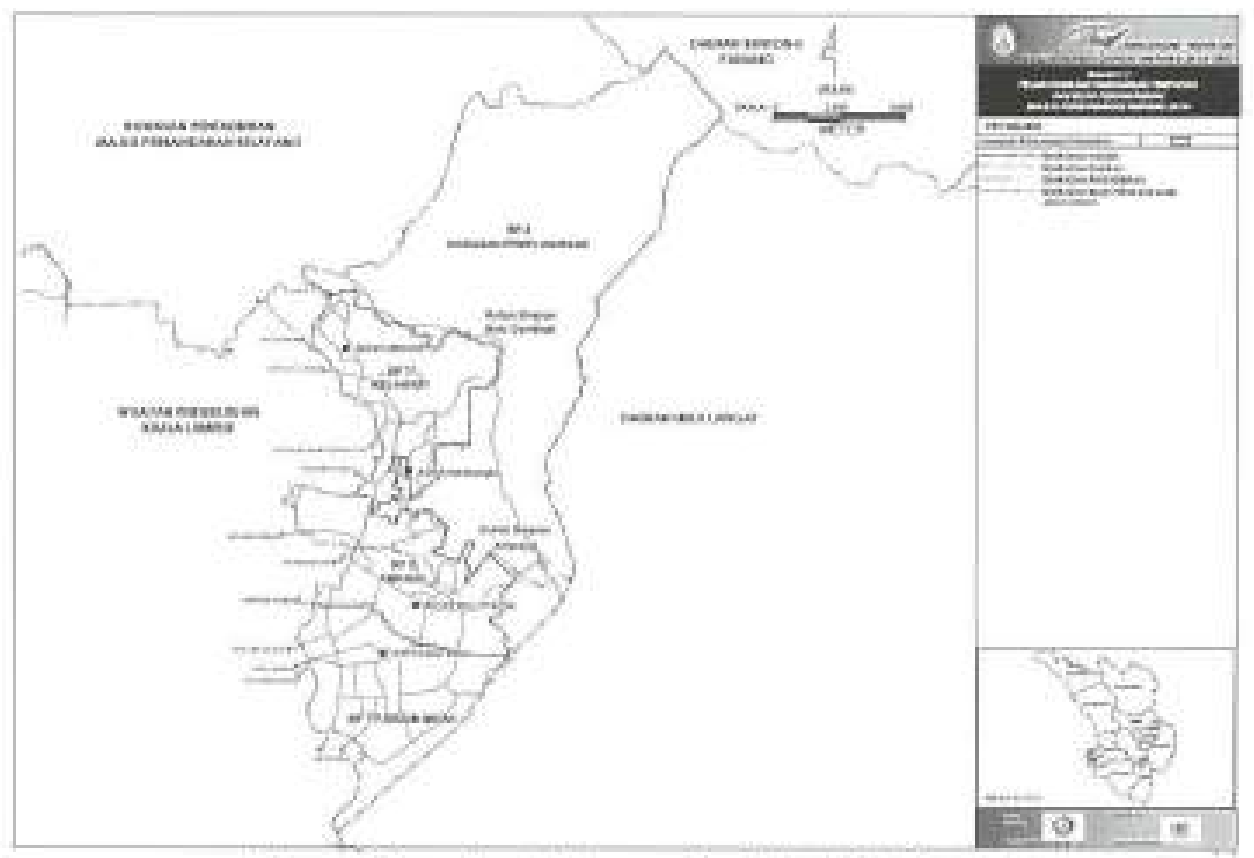

Figure 2: Location of Ampang Jaya Municipal Council

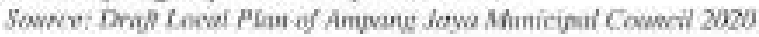

Table 1: Majlis Perbandaran Ampang Jays by Plamning Blocks (BP)

\begin{tabular}{|l|c|}
\hline P'lanning Blocks & Area (Hectare) \\
\hline BP I : PANDAN INDAH & 2,056 \\
\hline BP 2 : AMPANG & 1,880 \\
\hline BP 3 : TAMAN MELAW WTI & 1.823 \\
\hline $\begin{array}{l}\text { BP 4 : CONSERVATION AREA } \\
\text { (Hulu Gombak Reservo Forest) }\end{array}$ & $\mathbf{6 . 5 9 1}$ \\
\hline Total & 14,350 \\
\hline
\end{tabular}

Ampang Jaya has a population of 608,030 people in 2007 (Dept of Statistic, Malaysia). The district registered a relative increase in population from 478,613 in 2000 to 577,828 people in 2005 . Table 2 shows the population distribution by planning blocks for 2000,2005 and 2007 . 
Table 2: Population in Ampang Jaya District

\begin{tabular}{|l|c|c|c|}
\hline Planning Block & $\mathbf{2 0 0 0}$ & $\mathbf{2 0 0 5}$ & $\mathbf{2 0 0 7}$ \\
\hline Pandan Indah & 239,437 & 284,060 & 296,678 \\
\hline Ampang & 168,554 & 206,274 & 218,246 \\
\hline Taman Melawati & 60,474 & 75,376 & 80,289 \\
\hline Conservation Area & 10,148 & 12,118 & 12,817 \\
\hline Total & 478,613 & $\mathbf{5 7 7 , 8 2 8}$ & $\mathbf{6 0 8 , 0 3 0}$ \\
\hline
\end{tabular}

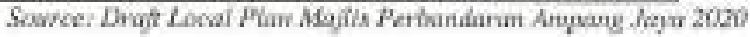

\section{METHODOLOGY}

\section{Data Collection}

Digital data on land use were obtained from MPAJ, while data on crimes were acquired from the Police District Headquarters of Ampang Jaya. Data on drug abuse were obtained from National Anti-Drug Agency (AADK). A total of 2,062 eases of crime recorded in 2008 were plotted manually using ArcGIS 9.2 as an individual point, geocoded by $\mathrm{X}$ and $\mathrm{Y}$ coordinates with the necessary attributes. Estimates on locations were made when the exact location of the crime were not recorded. Beyond these coordinates each point has additional attributes illustrating time, date, day, type of crime, type of drugs, location, small planning block and housing scheme. Figure 3 shows the spatial distribution and the parterns of crime incidents in MPAJ. These are classified into four crime incidents namely, (i) theft, (ii) snatch theft, (iii) night time burglary, and (iv) day time burglary.

Based on the recorded crime data, theft accounts for one-third (or $36 \%$ ) of the total crimes reported in 2008. Therefore, this study assumed that drug abusers tend to commit theft and snatch theft compared to night and day time burglary based on opportunity to commit crime, casy target and easy planning. 


\section{Influencing factors analysis}

This analysis was executed based on the results from the hotspot analysis for theft, snatch theft and drug abuse. Figure 4 show the land use verification of Taman Pandan Indah based on Google Earth image. Taman Pandan Indah consists of $40 \%$ residential area and $60 \%$ commercial. The hotspot locations of theft, 5natch theft and drug abuse is overlaid with the Google Earth image to facilitate the analysis of influencing factors to criminal incidents.

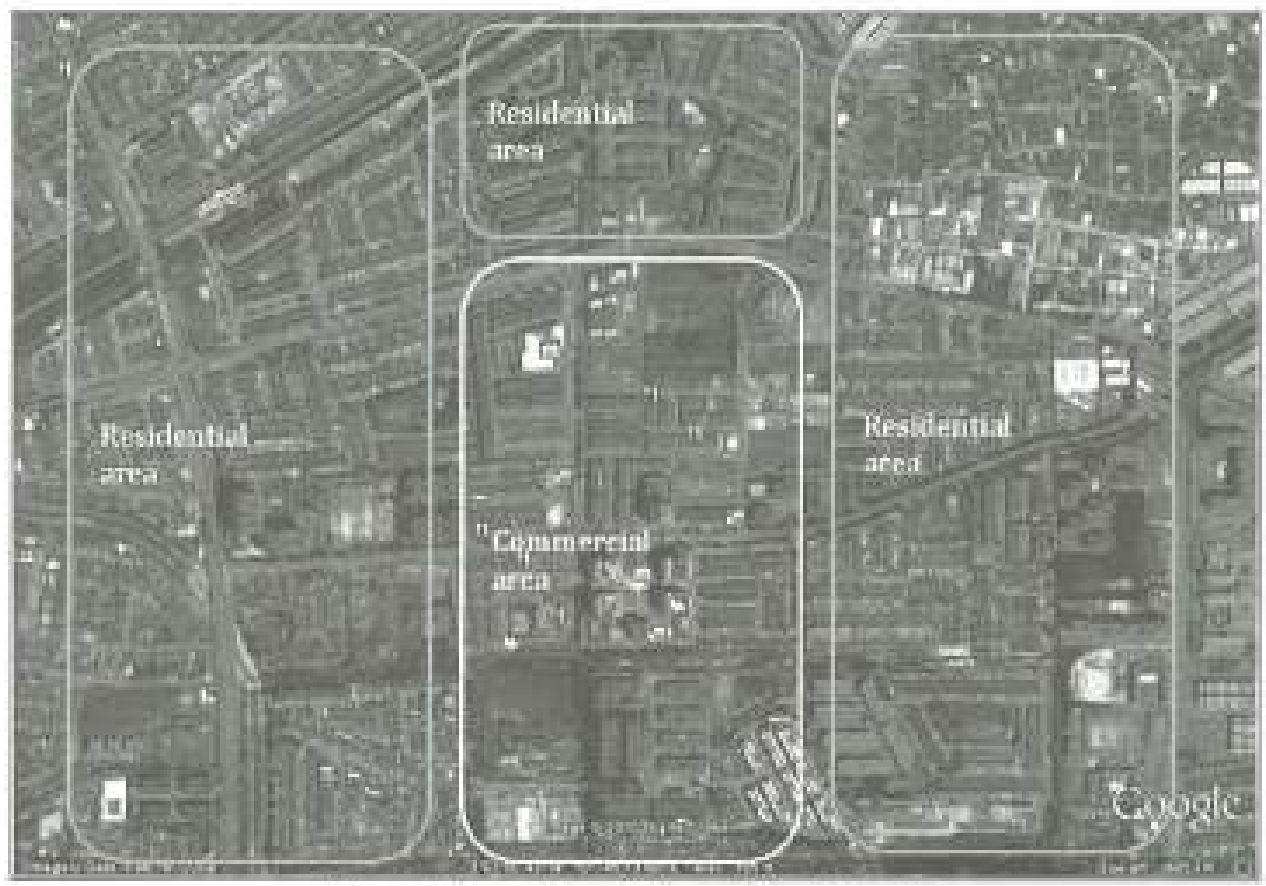

Figure 4: Land Use of Taman Pandan Indah

Source: Gosog be Earve Image

\section{Mostement Pattern Analyxis}

The movement analysis is conducted using Mean Centre and Standard Deviational Ellipse (SDE) technique. The mean centre is the point whose coordinates are the mean $x$-coordinate and mean $y$-coordinute for all the features in the study area. The SDE technique is a measurement of the difference between the average distance and the distance from a given feature to the mean centre. Based on reported offences, SDE would identify the direction criminal offenders select their target area. The measurement can be obtained using equation (4): 


$$
S D=\sqrt{\frac{\Sigma_{i}\left(x_{i}-X\right)^{2}}{n}+\frac{\Sigma_{i}\left(x_{i}-X\right)^{2}}{n}}
$$

The SDE is employed to indicate the geographic centre, distribution, orientation and directionality that exist for each crime, especially in understanding how the crime trans-change overtime in day and time categories. Standard deviation ellipse is a logical extension of the standard distance circle (Furley 1927) which can capture the directional bias in a point distribution (Wong \& Lee 2005). In movement pattern analysis, both theft and snateh theft are analysed by day and time categories. Day eategory is divided into two subcategories which are weekdays and weekends, whilst time categories are divided into five subeategories in 24-hour time format as shown in Table 3.

Table 3: Time Frame Subcategories
\begin{tabular}{|c|c|}
\hline ID & Time Frame \\
\hline 1 & $0000-0359$ \\
\hline 2 & $0400-0859$ \\
\hline 3 & $0900-1659$ \\
\hline 4 & $1700-1959$ \\
\hline 5 & $2000-2359$ \\
\hline
\end{tabular}

\section{FINDINGS}

Most of the hotspot areas for theft, snatch theft and drug abuse were deteeted in the southern region of MPAJ especially in Pandan Indah, whilst, the cold spot areas are distributed in the north of study area as shown in Figure 5. A further botspot analysis was executed based on overall reported cases of theft and snatch theft in Taman Pandan Indah area to identify the hotspot location (Figure 6). 

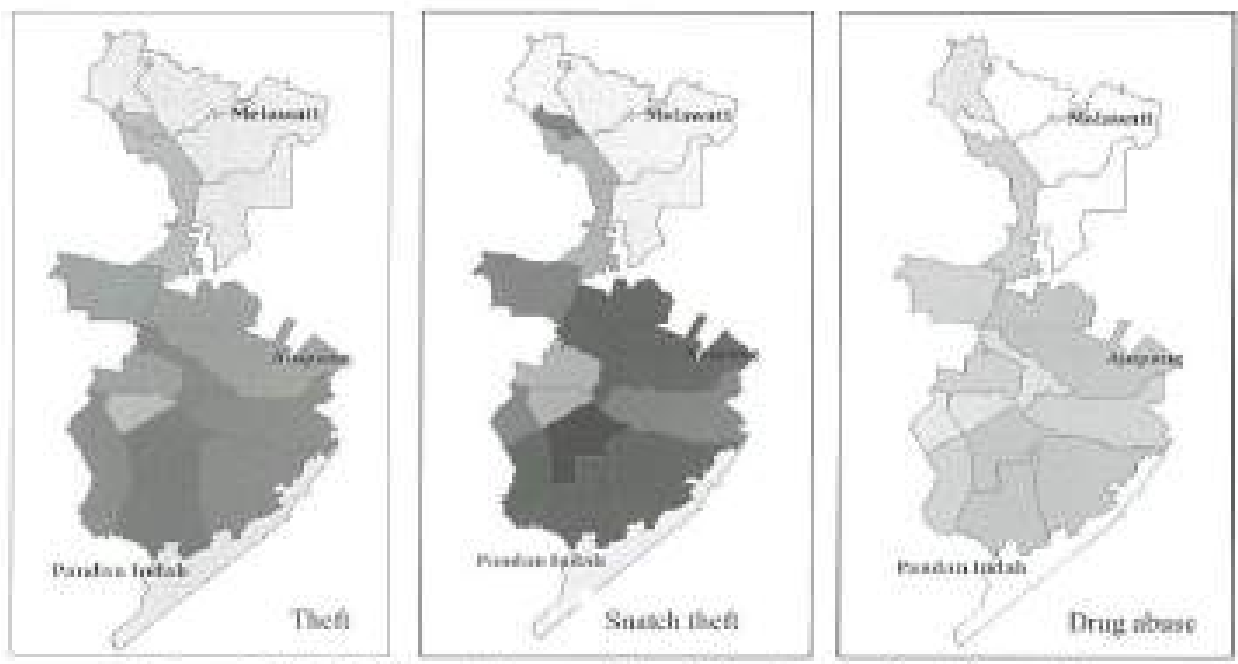

Figure 5: AJMC Hotspot Areas of Theft, Snateh Theft and Drug Abuse
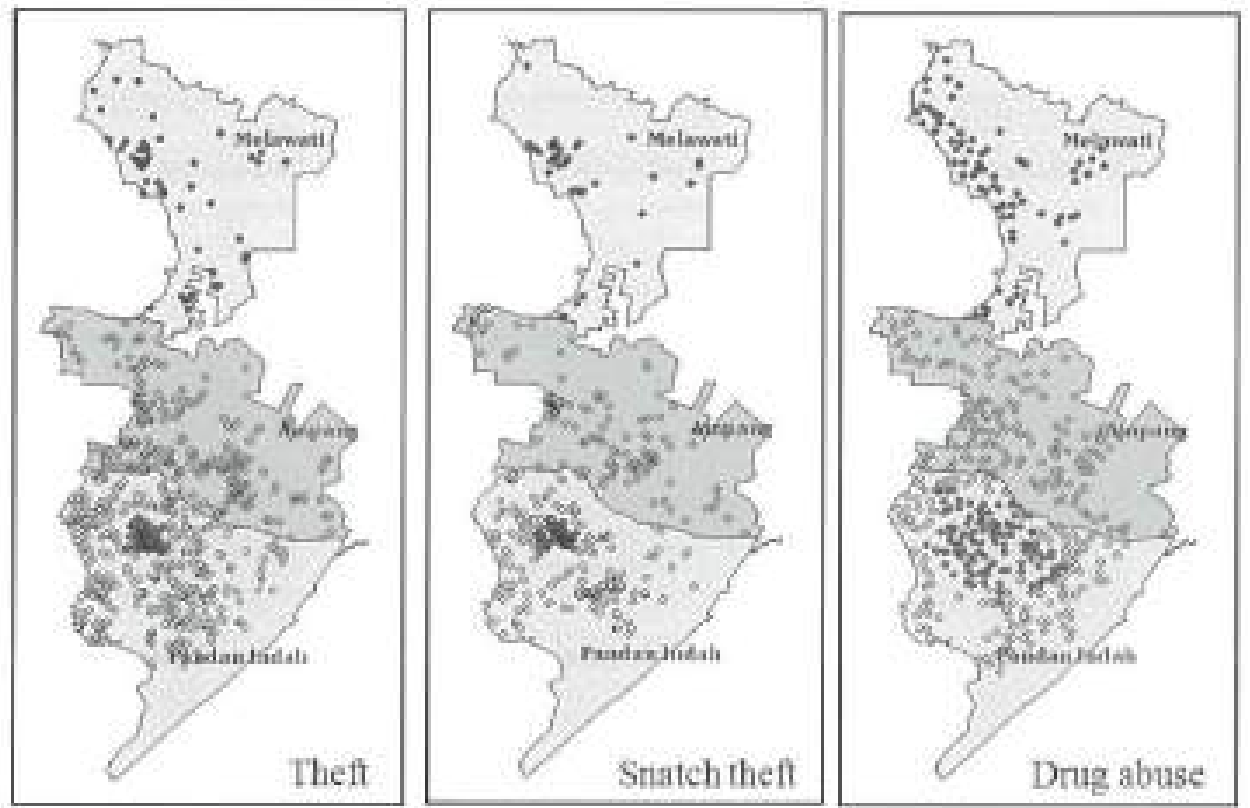

Figure 6: Hotspot Location based on overall reported Theft and Snateb Theft in MPAJ 
Based on the results of the hotspot analysis for theft, snatch theft and drug abuse, the influencing factor analysis was conducted on Google Earth image of Taman Pandan Indah. Taman Pandan Indah was selected due to the high number of reported cases recorded for the entire MPAJ. In Figure 7 and 8 , the hotspot location of crimes are indicated as cross marks and drug abuse distributions are indicated as small circle dots. The botspot area is in the commercial centre comprising of banks, clinics, restaurants, and a shopping mall, A feature with a high value may denote some form on concentration in crime incidence, but may not be a statistically significant hotspot.

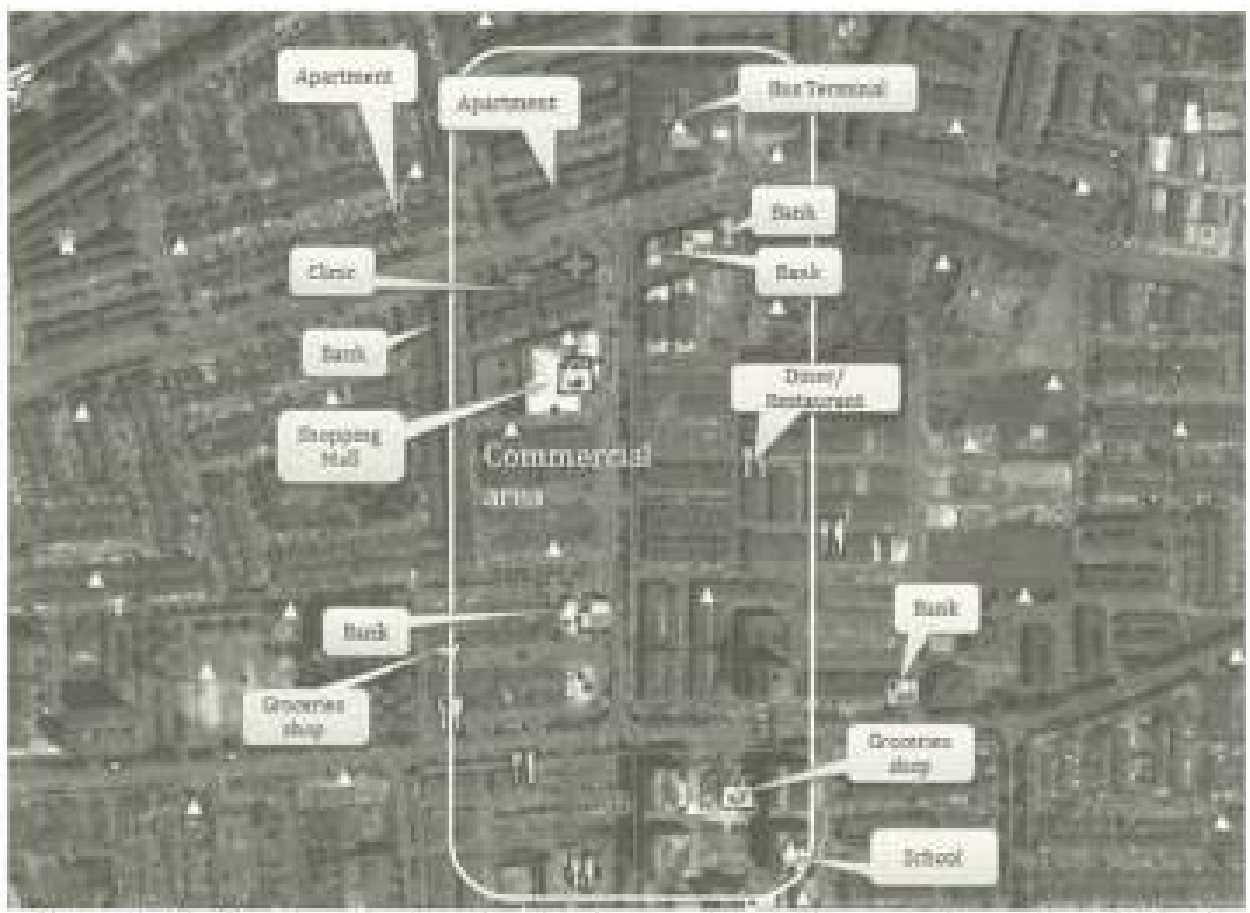

Figure 7; Theft occurrence besed on land use and drug abuse overlay of Google Earth image 


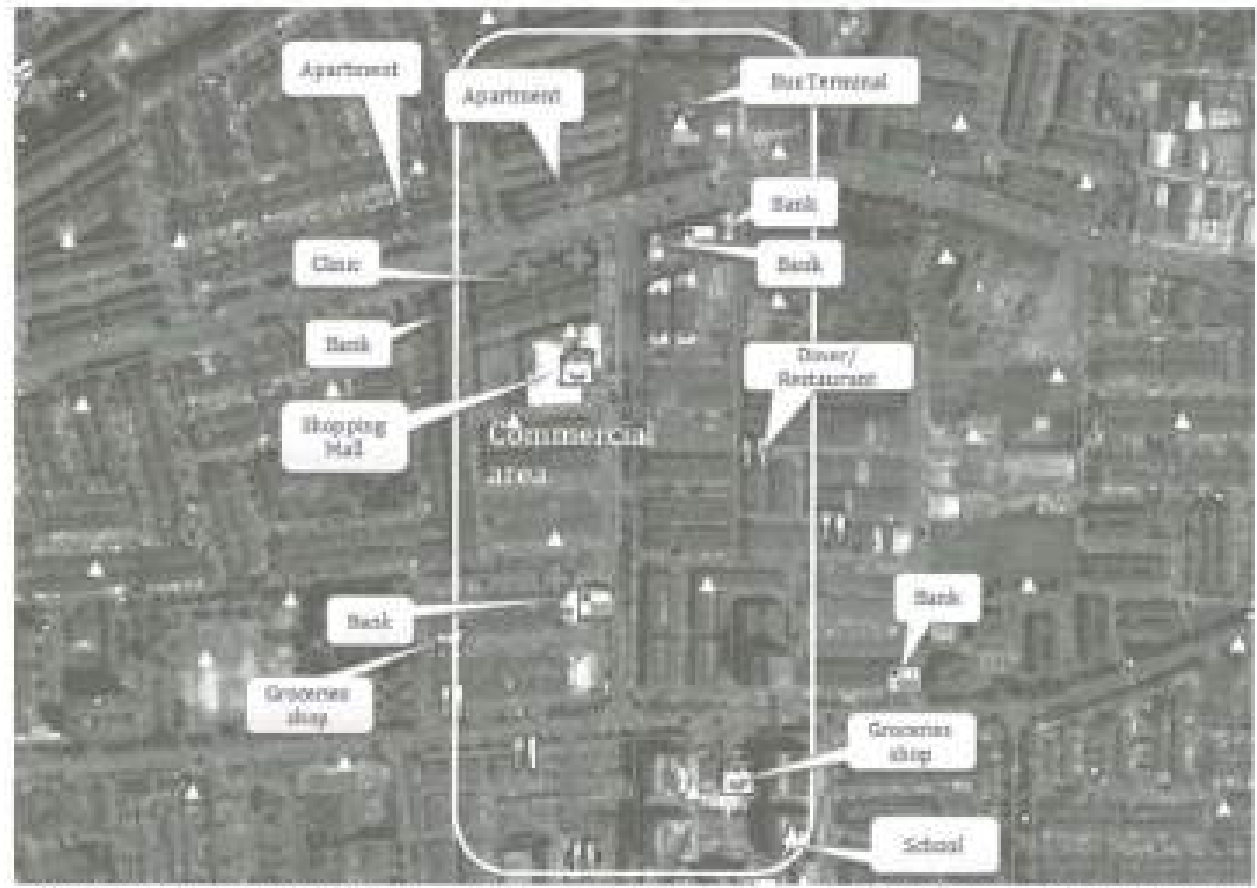

Figure 8; Snaich Theft Occurrence based on Land Use and Drug Abuse factor overlay of Google Earth Image

Based on the influencing fietor analysis, planning of the land use is a major contributing factor other than the likely availability of a victim. The findings of the study indicate that, drug abuse and criminal patterns are related to land use. The movement pattern analysis indicate that crime patterns in MPAJ tend to concentrate more in Pandan Indah and Ampang planning block.

As shown in Figure 9(a) and (b), the current tendency for all crimes are in the southern region of the ellipse. Similarly, the pattern of drug abuse distribution was found to be near theft and snatch-theft locations. This supports the contention that, there is a relationship between drug abuse, erime and fand use. Main roads, pedestrian bridges, commercial facilities such as banks, shopping complexes, bus stands and restaurants appear to be the preferred locations for criminals to find their victims. The direction and concentration of crime as indicated by the SDE for both crimes seem to diselose that busy traffic and large crowds which present a high possibility of likely victims in open and strategic areas are relative opportunity elements for crime incidents.

Both theft and snatch theft are more frequent on weckdays compared to weekends, where 563 theft and 322 snatch theft eases are reported during 2008. 
PLANNIVG MALANSA

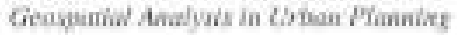
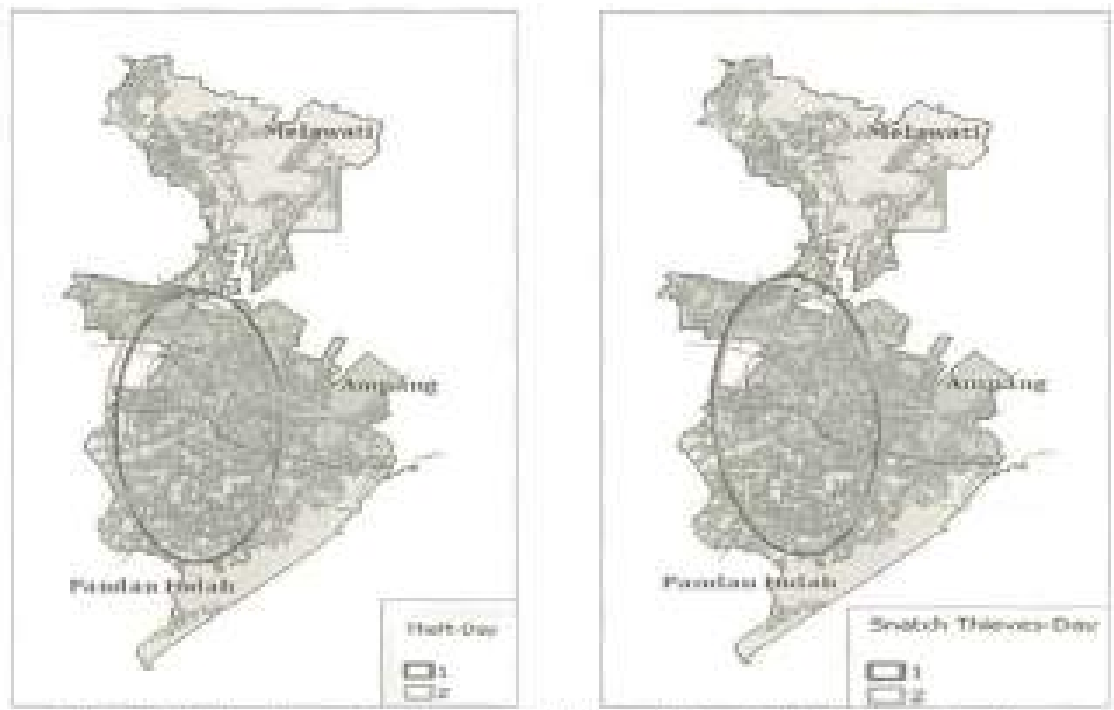

Figure 9(A): The Direction of Ellipses of Theft and Snateh Thett based on Day category
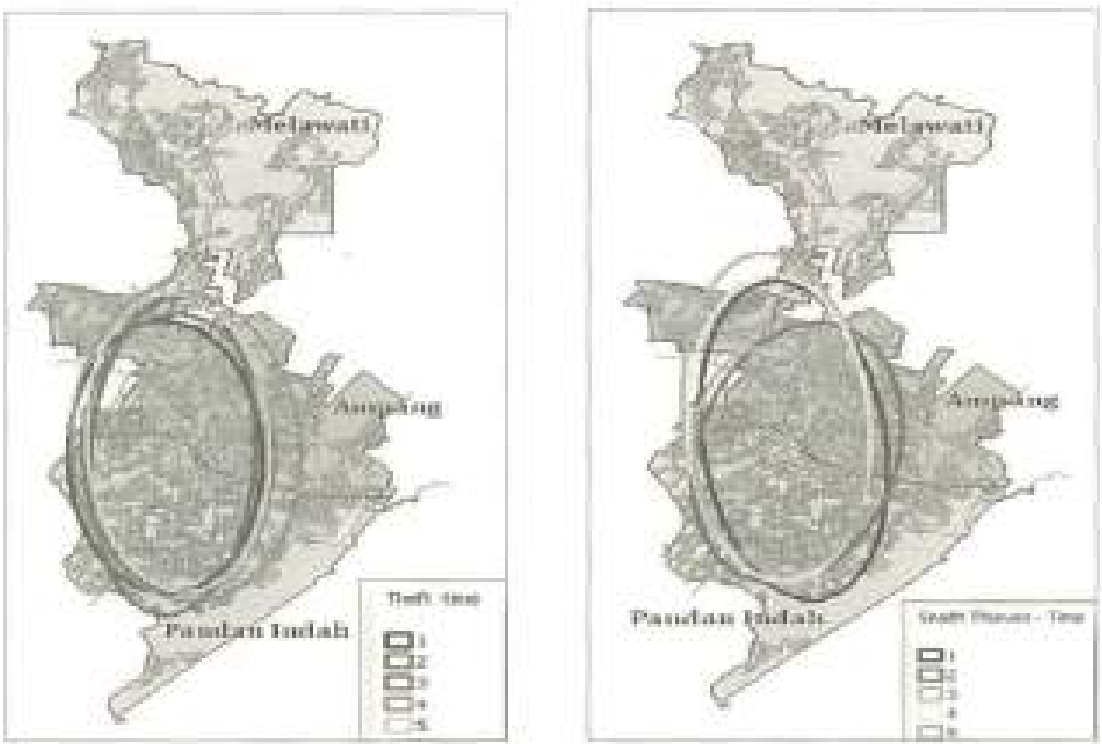

Figure 9(B): The Direetion of Ellipses of Theft and Sratch Theft based on Time Frame Category 
The mean centre technique elearly defined the movement pattern of theft and snatch theft by time. As the duily activities of likely victims change the hotspots from crime incidence also changes. Figure 10(a) shows the movement pattern of both theft and snatch-theft during weekdays and weekends.
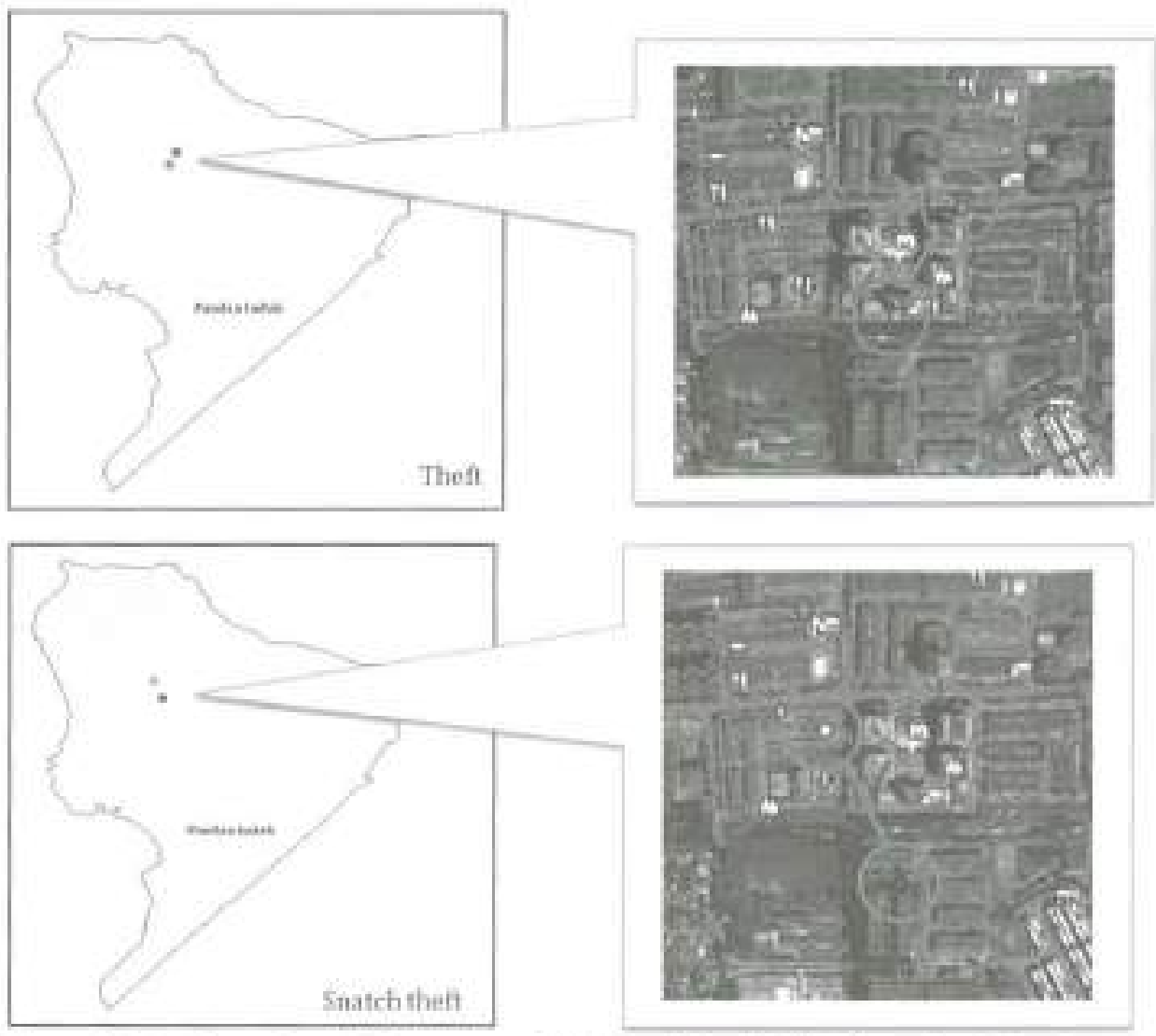

Figure 10(A): Mean Centre Movemient of Theft and Snatch Theft based on Day Category

The time subcategories data indicate that, the highest number of theft took place between $4: 00$ am to $8: 59$ am, whilst snatch-thef occurred between 9:00 am to 4:59 pm. The movement pattern of both criminal activities as shown in Figure 10(b) is based on the mean centre, calculated according to the time frame subcategories. The movement pattern begins from time frame I (00:00 $03: 59)$ to time frame $5(20 ; 00-23: 59)$ as shown in Table 3 . 

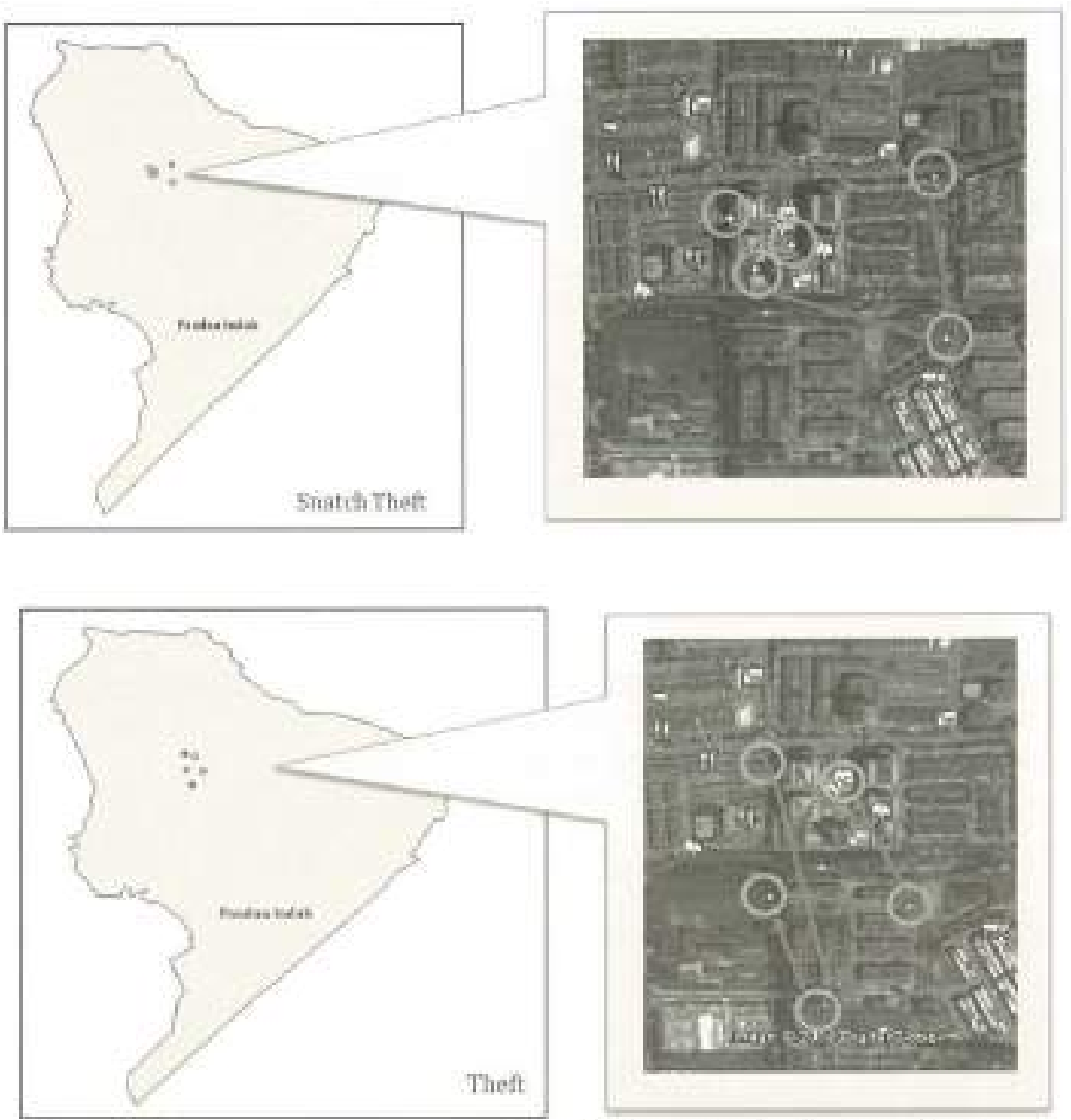

Figure $10(B)$ : Mean centre moveneat of theft and snatch theft based on time frame subcategories

The movement pattems in Figure 10(b) indicate that the occurrence of both criminal acts originates at residential area close to target spot (restaurant or bank) and as the night progresses to daylight (04:00-08-59), the offenders target the residential area. The offenders then shift their target area to a bigger area of likely victim located mostly in commercial centre and its surrounding during daylight $(09: 00-16: 59$ ). As the night progresses (20:00-23-59), the criminal acts are centred in the commercial areas. From the analysis, it is concluded that the offenders tend to change their target area based on the crowd and land use. The offenders select target areas that are relatively near to oommercial centre such as banks, schools, diners or restaurants and residential areas. 


\section{CONCLUSIONS}

This study shows that there is a measurable link between criminal activities and physical or social space. It supports the opportunity theory which implies that crime density and population density are conceptually related. The mean centre of each crime distribution for MPAJ also identifies with this suggestion. The mean centre of crime is located in Taman Pandan Indah, an urban area with a dense population. The analyses were curried out for each crime based on categories and subcategories. Each category is further split into groups that are weighted. Each day category is weighted according to week-day and weekend subcategories, and the time category is weighted into five subcategories or time fiame.

The crime distribution in MPAJ displayed a highly elustered pattern for every erime type. Clustered means crime rates are concentrated in a certain area. The spatial result showed that crime patterns in the study area are elustered with high value and the land use bas a correlation with crime nctivities. Results from the analysis according to time frame also resulted in significant change of erime pattem. These findings revealed the sqatial cocrelation between types and pattems of criminal activities and land use namely commercial (banks and shopping malls) and residential areas. The opportune spots for criminals are at roads with heavy traffic, pedestrian bridges and bus stops. The tempora! GIS dimension of the study has provided a clearer understanding on the pattern of crimes and drug abosers in relation to land use planning

The integration of spatial statistics and GIS can assist local authorities and police departments in particular, to identify hotspots for crime incidence. Implementation of the safe sity initiative by the Government and CPTED in residential layout design is potentially a more effective way to combat urban crime and insecurity of the Malaysian urban society, 


\section{REFERENCES}

Allen C.B. (2005). The Links between Heroin, Crack Cocaine and Crime: Where Does Street Crime Fit in? British Journal of Criminology, Vol. 45 (3), 355-372.

Amler, B., Betke, D., Eger, H., Ehrich, Chr, Hoesie, U., Kohler, A., Küsel, C., Lossau, A. V., Lutz, W, Muller, U, Schwedersky, T, Seidemann, S., Siebert, M., Trux, A., Zimmermann, W. (1999). Land Use Planning: Methods, Strategies and Tools. Universum Verlagsanstalt, Eschborn, Germany.

Atias, R.I. (2008). 2l" Century Sccurity and CPTED: Designing for Critical Infrastructure Protection and Crime Prevention. Taylor \& Franeis Group, LLC, Boca Ratan, FL.

Brantingham, P. J. and Brantingham, P. L. (1981). Environmental Criminology: Beverly Hills, CA: Sage Publications.

Brantingham, P. J. and Brantingham, P. L. (1984). Patterns in crine, New York City, NY: Macmillan Publishing Company.

Brochu, S., (1995). Drogue et Crininalite. Une Relation Complese, Collection Perspectives Criminologiques, Presses de I'Université de Montríal.

Chainey, S. and Rateliffe, I. (2005). G7S and Crime Mapping. West Sussex, England: John Wiley and Sons, Ltd.

Clarke R.V. (1992). Situational Crime Prevention: Successful Case Studies. New York, NY: Harrow and Heston Publishers.

Clinard, M.B. and Meier, R. F. (1995). Sociology of Deviant Behaviour, 9 Edition. New York: Harcourt Brace College Publishers.

City of Orlando. (2008), Crime Prevention through Environmental Destgn: Your Guide to Creating a Safe Environment. City of Orlando, Orlando, Florida.

Cohen, L. E. \& Felson, M. (1979). Social Change and Crime Rate Trends: A Routine Activity Approach. American Sociological Review, 44, $588-$ 608 ,

Comish D.B. \& Clarke, R.V. (1986). The Reasoning Crimutnal: The Rational Choice Perspectives on Offending. New York, NY: Springer Verlag.

Everitt, B. (1974). Cluster Analysis. London: Heinemann Education Books. ESRI, (2007). GIS Technology and Application for the Fire Service, ESRI White Paper. March 2006. [Accessed 18 July 2011].

Felson, M. (1987). Routine Activities and Crime Prevention in the Developing Metropolis. Criminology, 25 (4), 911 - 931 .

Fisher, B., (1999), Mlicit Opiates in Toronto: A Profile of Current Users. Addiction Rexearch, 7(5), 377-415. 
Freelan, S., (2003). Developing a Quasi-Temporal GIS for Archival Map Data. http://proceedings.esti.com/ibrary/userconf/proc03/p0987.pdf. [Accessed 19 July 2011].

Furley, P. (1927). A Note on Lefever's : Standard Deviational Ellips. American Journal of Sociology 23, 94-98.

Getis, Arthur, and Ord, J. (1992). The Analysis of Spatial Association by Use of Distance Statistics. Geographical Analysis 24, 189-206,

Grubesic, T, H, and Murray, A, T. (2000). Detecting Hotspots using Cluster Analysis and GIS. Research Paper for the Center for Urban and Regional Analysis and Department of Geography, Ohio State University, Columbus, Ohio.

GTP, (2011). Program Transformasi Kerajaan. Laporan Tahunan 2010. Unit Pengurusan Prestasi dan Pelaksanaan (PEMANDU), Jabatan Perdana Menteri.

Gymfi, J. A. (2002). An Analysis of the Broad Crime Trends and Patterns in Ghans. Journal of Criminal Justice 30, 229-243.

Harrsies, K. (2006). Extreme Spatial Variations in Crime Density in Baltimore County, MD. Geoforim 37, $404-416$.

Jeffery, C. R. (1971). Crime Prevention through Environmerrat Dexign. Beverty Hills, CA: Sage Publishing Company,

JPBD Johor, (2010). Program Bandar Selamat. btip//www jpbdjohor,goy, my/2/index main.php?pm perkhidmatan\&p? = bandarselamat. [Acoessed 20 July 2011]

JPBD NS, 2010. Pelaksanaan Program Bandar Selamat Di Negeri Sembilan. Buletin Rancang. Buletin Jawatankuasa Perancang Negeri, Negeri Sembilan Danul Khusus. Bil. 1/2010, 10-13.

Karofi, U. A., (2005). Drug Abuse and Criminal Behaviour in Penang, Malaysia: A Multivariate Analysis, Bungladesh e Journal of Sociology, 2, 1-26.

Klinkenberg B. (200)8). GIS and Crime http://www.geogube.ca/courses/geob479/notes/crime/Crime intro pdf. [Accessed on August 4, 2010].

Lawrence, S., Gartin, P., and Buerger, M. (1989). Hotspots of Predatory Crime: Routine Activities and the Criminology of Place. Criminology, 27, 27. 55.

Murray, A. M. (2001). Exploratory Spatial Data Analysis Techniques for Examining Urban Crime Implications for Evaluating Treatment, British Journal of Criminology $41(2), 309-329$.

Nation Master, (2010). Crime Statistics: Total crimes (per copita) (most recent) by country http//www nationmaster.com/graph/cri tot_cri percapcrime-total-crimes-per-capita. [Accessed February 1, 2010]. 
Navanatnam, V. (1990), Drug Use among Malaysian Youth: Selangor: Jawatankuasa Anti Dadah Negari Selangor, Revised by the National Drug Research Centre of Drug Research, University Science Malaysia.

NCPC, (2003), Crime Prevention through Environmental Design Guidebook. National Crime Prevention Council, Singapore.

NKRA, 2011. Q \& A Enam Bidang Keberhasilan Utama Negara (NKRA). http:/pmr.penerangan,gov,my/index.php?option=com_content\&viewsart icle\&id=4808:pointers-6-bidang-keberhasilan-utama-negarankra\&catid=16:isu-nasional [Accessed 14 January 2011].

Ord, J., and Getis, A. (1995). Local Spatial Autocorrelation Statistics: Distributional Issues and an Application. Geographical Analysis, 27, 286-306.

Rogerson, P., Batta, R., and Rump, C. (2003). Defection and Prediction of Geographical Changes in Crime Rates. Executive Summary. U.S Department of Justice,

Roncek, D., and Maier, P. (1991). Bars, Blocks, and Crime Revisited: Linking the Theory of Routine Activities to the Empirical of Hotspots. Criminology $29,725-753$.

SCRIBD, (2011). Definisi Dadah. http://www.scribd.com/doc/6781412/ definisidadah. [Accessed 20 December 2010].

Schneider, R.H. \& Kitchen. T, (2013). Putting Crime Prevention through Envirommental Design into Practioe via Planning Systems: A Comparison of Experience in the US and UK, Built Environment, Vol. 39(1), 9-30

Sidhu, A. S. (2006). Crime Level and Trends in the Next Decade. Journal of the Knala Lunpur Royal Malaysia Police College, No. 5, 1-13.

Sherman, L. W. (1995). Hotspots of Crime and Criminal careers of Places In: Eck, J.E., Weisburd, D. (Eds.), Crime and Place, The Police Executive Research Forum, Monsey, Washington, DC, New York: Criminal Justice Press.

Suryavanshi, V. M. (2001). Land Use and Opportunities for Crime: Using GIS as an Analysis Tool. Master Thesis of Urban and Regional Planning, Virginia Polytechnic Institute and State University (Virginia Tech), Blacksburg, VA.

Tabagin, D., Flores, J. C., and Emperador, N, F., (2008), Investigating Crime Hotspot Places and their Implication to Urban Environmental Design: A gcographic Visualization and Data Mining Approach. World Academy of Sciences, Engineering and Technology, 48, 16-24.

Utusan Online, (2009). 50 peratus kes ragut dilakukan penagih dadah. 17 April 2009.

http: $/$ www.utusan.com.my/utusan/info,asp? $y=2009 \& d t=0418 \& p u b=$ Utu san_Malaysia\&sec=Jenayah\&pg $=j 0$ 05.htm. [Accessed 28 July 2011], Utusan Malaysia, (2009). Penagith Punca Ragut. 12 September 2009. 
The Star, (2008). Snatch-thieves slash Samaritan. 26 November 2008. htip://scotthong,wordpress.com/tag/johor-snatch-theft/. [Accessed 28 July 2011].

The Star, (2009). Dawghiser of Snatch-theft Victim Vows to Seek Revenge. 29 May 2009.

http:/thestar.com.my/news/story.asp? sec-nationdfile $=/ 2009 / 5 / 29 /$ nation/ 4005019. [Accessed 28 July 2011].

The Star, (2009). Snatch Theff Vicrim Badly Injured. 28 November 2009. http:/thestar.com.my/news/story.asp?file $=/ 2009 / 11 / 28 / n a t i o n / 5201609 \&$ sec-nation. [Accessed 28 July 2011].

The Star, (2010). Tutor Cheats Death in Snatch Theft Incidents. 8 October 2010. http:/thestar.com.my/news/story,asp?sec-nation\&file $=/ 2010 / 10 / 8 /$ nation/ 7186936 [Accessed 28 July 2011].

Vasudevan, V, (2008), Rising Crime Index Has Ahdullah Worried. News Straits Times.

Wong, D. W., \& Lee. J. (2005). Statistical Analysis of Geographic Information With Arc View GIS and ArcGIS. Hoboken, New Jersey: John Wiley and Sons, Inc.

Zin, M.M (2009). Perangi Dodah Bagi Mengatasi Jenayah. http:/www.ikim,gov,my/v5/index.php/imagesweb/ikim/file/file/index.ph p? $\mathrm{g}=1$ \& opt $=$ com articledgrp $=2 \&$ sec $=$ \&key $=2031$ \&cmd-resetall. [Accessed 20 July 2011]. 